\title{
MATHEMATICAL MODELING: EFFECTS ON PROBLEM SOLVING PERFORMANCE AND MATH ANXIETY OF STUDENTS
}

\author{
Ma. Lian Kamyl P. Santos ${ }^{1}$, Rene R. Belecina ${ }^{2}$, Rosemarievic V. Diaz ${ }^{3}$ \\ ${ }^{1}$ Cavite State University, Philippines \\ ${ }^{2}$ Philippine Normal University, Philippines \\ ${ }^{3}$ Philippine Normal University, Philippines \\ E-mail address: rrdelecina@yahoo.com,rvdiaz@yahoo.com
}

Keywords: mathematical modeling, strategies in teaching, problem solving, math anxiety

\begin{abstract}
This study determined the effects of the integration of mathematical modeling on the problem solving performance and math anxiety level of Grade 9 students. Two groups of students were exposed to different strategies: the control group was taught using guided practice while the experimental group was taught using the integration of mathematical modelling. Pretests and Posttests were given to measure the performance of both groups in terms of their problem solving skills and their math anxiety level. T-test of independent and dependent were used to determine whether there exists significant difference between the performance of the two groups in terms of their pretest and posttest scores. Questionnaire and Interview Method were implemented were used to elicit students' reactions on the integration of mathematical modeling in the classroom.

Findings showed that there is a significant difference between the pretest and posttest mean scores of both groups in terms of their problem solving performance test and their mathematics anxiety test. However, when their posttest mean scores were compared, the experimental group made a large improvement in terms of their problem solving performance and a reduction in terms of their mathematics anxiety level, thus, the integration of mathematical modeling was effective in improving the problem solving performance and reducing the math anxiety level of students.
\end{abstract}

\section{INTRODUCTION}

Mathematics is very important in our lives. The application of mathematics is evident not only in the field of education, but in almost every aspect that we could think of: when we budget our monthly income, manage our time, and even in the infrastructures we see outside. In the Philippine education system, mathematics is one of the top priorities in terms of the number of hours allocated per class in all levels. The Department of Education (DepEd) mandated 50-minute time allocation everyday in the old curriculum (Revised Basic Education Curriculum) and 1 hour for 4 days for the new curriculum ( $\mathrm{K}$ to 12 Curriculum). Mathematics is also one of the subjects included in assessing one's achievement in terms of national level competency like the National Career Assessment Examination and the National Achievement Test. In wanting to develop mathematical competency in the subject, to promote good camaraderie skills between students, and to establish rapport between teachers and students, various mathematics trainings for students and teachers are held in the country such as the Mathematics Teachers Association of the Philippines (MTAP) trainings and the Mathematics Trainers' Guild apart from the different mathematics enrichment and remedial programs advocated by various schools both in the private and public sectors.

Given the attention that the Philippine education system is dedicating to Mathematics, there are still various issues and difficulties arising in teaching and learning the subject. This is in agreement with the statement made by Alkan (2013) who said that ever since the introduction of mathematics in the curriculum, mathematics has always been viewed as a problem area for pupils. In relation to that, it has been reported that during the 2003 Trends in International Mathematics and Science Study, the Philippines ranked near bottom: third from the bottom in the fourth grade and fifth from the bottom in the eighth grade (Culaste, 2011). 
Among the many issues and concerns related to Mathematics teaching and learning, the most common are the problem solving performance of students and the math anxiety level of students (Corrective Math, n.d.; Hewson, n.d.). Problem solving plays an important role in mathematics and has a prominent role in the mathematics education of K-12 students but mathematics teachers are oblivious in incorporating meaningful problem solving into their classroom teaching (National Council of Teacher of Mathematics, 2010). In the Philippines, a study made by Dela Cruz and Lapinid (2014) has shown that $40 \%$ of their respondents are below the satisfactory level in translating worded problems due to the following difficulties: carelessness, lack of comprehension, interchanging values, and unfamiliar words. When it comes to the math anxiety level of students, Beilock (as cited in Harms, 2012) found out that students report worry and fear about doing mathematics as early as first grade and even the highest-achieving students, who typically have the most working memory were also experiencing math anxiety. In the Philippines, attitude towards mathematics has always been a great concern and according to Lee - Chua (2012), mathematics is feared due to the following reasons: terror teachers, learned helplessness, neglectful or pressure-inducing parents, society's denigration of deep thought, instant gratification, lack of motivation, and failure in examinations.

According to Rysdon (2010), the greatest reason why students are performing poorly in mathematics is because they are still having a hard time finding the relevance of mathematics in their lives. Students are aware on how they are able to use the basic concepts of Mathematics in their daily lives but when it comes to more complicated mathematics topics and whenever students are experiencing difficulties, they begin to question its essence.

Teachers, on their part, are finding ways to make their classes love mathematics by trying out new techniques and teaching methods which would make students interested and engaged. With regard to that, there are plenty of teaching methods and strategies that the teachers could use, but this study utilized the integration of mathematical modeling because according to Kaiser, Blomhøj and Sriraman (as cited in Blomhøj, 2009), the introduction of mathematical modeling and applications is probably, together with the introduction of information technology, the most prominent common features in mathematics curricula reforms around the world.

\section{CONCEPTUAL FRAMEWORK}

This study is anchored on the mathematical modeling rooted on Lesh et al's translation model (as cited in Suh, 2007), which states that students make more meaningful connections when mathematical ideas are represented in multiple modes such as manipulative, pictures, real-life contexts, verbal symbols, and written symbols. This model emphasizes that translation within and among various modes of representation make concepts meaningful for students.

Aside from the model mentioned above, mathematical modeling stems from two learning theories: Social Constructivism and Metacognition. (Bahmaei, 2011; Wethall, 2011; Oswalt, 2012). In a Vygotskian's perspective, it asserts that an individual's learning is affected by the classroom or the outside world combined with those of the learner's previous knowledge (Cobb, as cited in Wethall, 2011). Another important learning theory that mathematical modeling upholds is the Theory of Metacognition by John Flavell which pertains to the ability of one person to think about his own thinking. Temur (2011) deeply stressed that when students are aware of their own or their peers' thinking processes or strategies, it will be easier for them to do analysis and model development while problem solving. For this group activity to be successful, each group member should work collectively with each other, manifest an open-minded nature, and develop a sense of ownership of the problem.

This is evident in the findings of Francisco and Maher (2005) where students developed ownership of the process of doing mathematics and of the resulting forms of the knowledge they built together.

Mathematical modeling is the ability to apply concepts learned in class to real world applications and to use the model to analyze a situation, draw conclusions, and make predictions. It 
is more than simply presenting the students with a word problem. It is a mathematical process that involves observing a situation, conjecturing relationships, applying mathematical analyses, obtaining mathematical results, and reinterpreting the model (Lingefjärd, 2006).

Figure 1 shows the simplified view of mathematical modeling process.

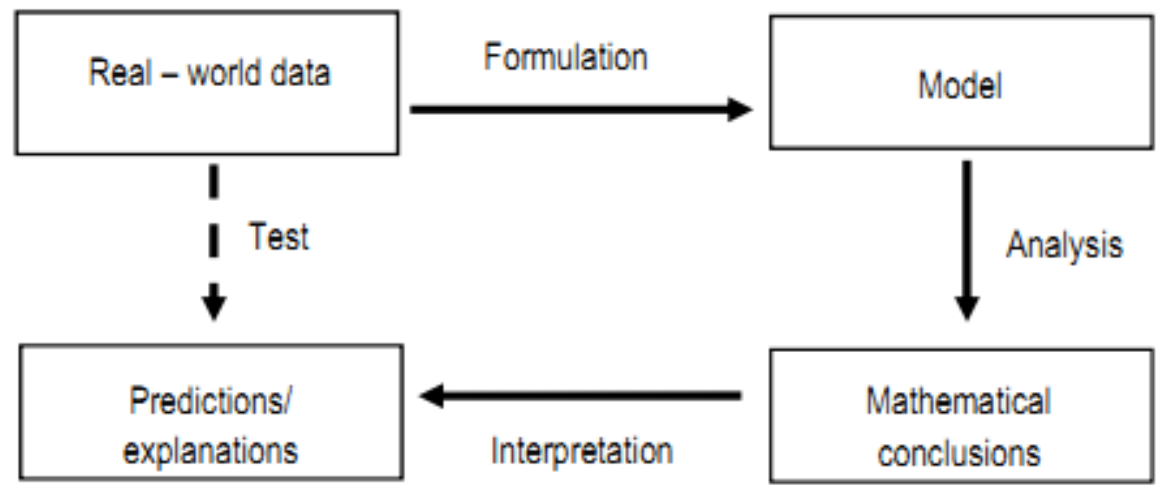

Figure 1. Simplified Mathematical Modeling Process (Cheng, 2001)

Various researches showed that mathematical modeling can help improve the problem solving ability and improve the math anxiety level of students, which were two of the most common problems in mathematics (Mousoulides, Pittalis, \& Christou, 2006; Parker \& Bedford, 2001; Das \& Das, 2013).

Taking into consideration the aforementioned different theories of leaning embedded on mathematical modeling, this study attempted to determine the effects of integrating mathematical modeling to the problem solving performance and math anxiety of Grade 9 students.

In this study, much is given importance to the process rather than the product. The study concentrated on the whole thinking process of the participants; on how they were able to process the given data and make their own mathematical model. Figure 2 shows how the integration of mathematical modeling, rooted on the following learning theories: Translation Model, Social Constructivism, and Theory of Metacognition, affects the problem solving performance and math anxiety of students

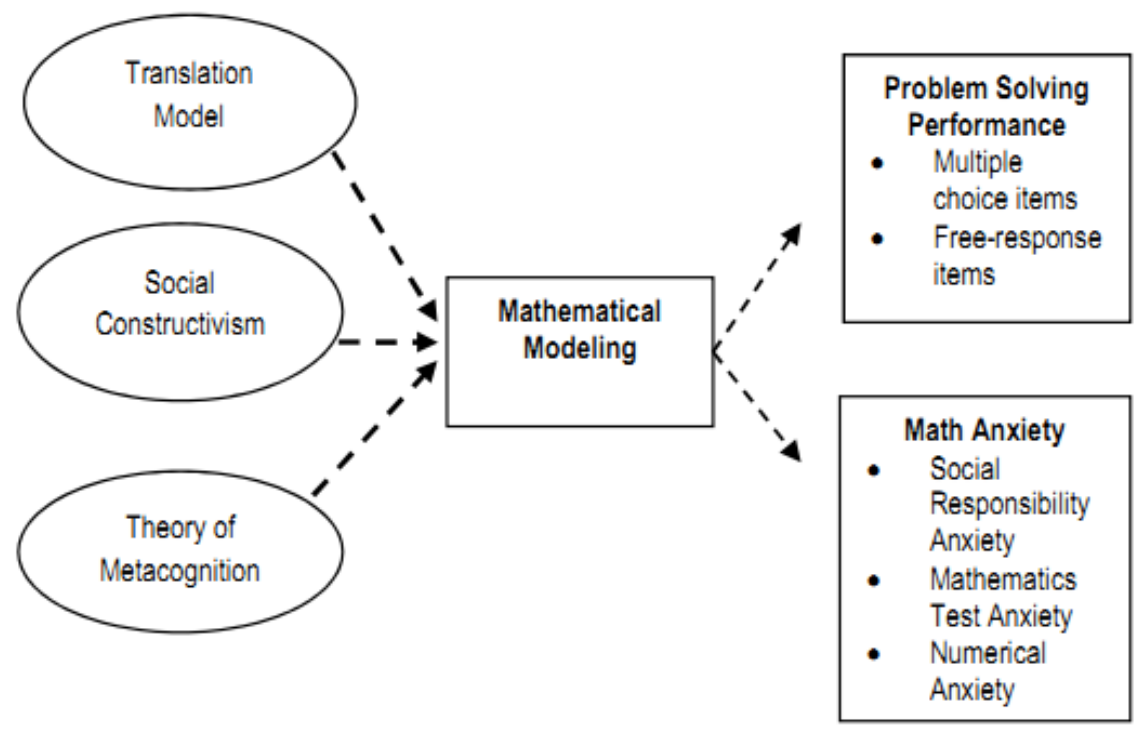

Figure 2. Conceptual Paradigm of the Study

In terms of determining the problem solving performance of students, a test was given in two parts: part I is composed of multiple choice items while part II is composed of free response items. In part I, since it is composed of multiple choice items, solutions are not important just as long as students were able to analyze and understand each given word problems/ situations while in 
part II, preparing the solution and the process of solving each item are given much importance especially in evaluating each answer. To determine the math anxiety level of students, a mathematics anxiety test was given which was categorized into three constructs: Social Responsibility Anxiety, Mathematics Test Anxiety, and Numerical Anxiety.

\section{STATEMENT OF THE PROBLEM}

The main purpose of this study was to determine the effects of the integration of mathematical modeling to the problem solving performance and math anxiety of students.

Specifically, it sought to find answers to the following specific questions:

1. Is there a significant difference between the pretest and posttest mean scores of the control and experimental groups in terms of:

1.1. Problem-solving performance?

1.2. Level of math anxiety?

2. Is there a significant difference between the posttest mean scores of the control and experimental groups in terms of:

2.1. Problem-solving performance?

2.2. Level of math anxiety?

\section{METHODOLOGY}

\section{Research Design}

The study employed the experimental design particularly the pre and posttest design, to compare the performance of the participants taught using the integration of mathematical modeling with another group, the control group, which was taught using guided practice. The experimental research design is appropriate to this study because it is the only design that can truly test a hypothesis concerning cause-and-effect relationship (Sevilla, et.al. , 1992).

\section{Participants of the Study}

The study employed intact groups and group matching techniques in selecting the participants of the study. The participants came from the Grade 9 students enrolled in Eastern Bacoor National High School. From the twelve heterogeneous sections, two sections (each composed with 46 students) were randomly chosen using the fishbowl technique to represent the control and experimental group. Between these two sections, a coin was tossed to determine which among the sections shall be the control group or the experimental group.

To ensure that no other underlying factors would interfere with the results of the study, aside from the variables presented in the conceptual paradigm, both groups were handled by the same teacher, their classroom location is within the same area, and their class schedule interval is comparable.

Group matching techniques were used so that each group will have an equal distribution of learners according to their mathematical ability: above average, average, and below average. The basis of their classification is their $2^{\text {nd }}$ grading period grade in Mathematics. The scale used in the classification of the student's ability level was adopted from Basco (2008) as seen in table 1.

Table 1. Basis of Classification in terms of students' mathematical ability (Basco, 2008)

\begin{tabular}{cc|}
\hline Grade & Classification \\
\hline $\mathbf{8 6}$ and above & Above Average (AA) \\
$\mathbf{8 0 - \mathbf { 8 5 }}$ & Average (A) \\
$\mathbf{7 9}$ and below & Below Average (BA) \\
\hline
\end{tabular}

As revealed in table 1 , there are three classifications of mathematical ability namely: below average; average and above average. The researchers made sure that this three types of students are well represented in each of the two groups under study. 


\section{RESEARCH INSTRUMENTS}

The instruments that were used in gathering data from the participants are the following: Problem Solving Performance Test, composed of multiple choice items and free-response items, which seeks to measure the problem solving performance of the students; Mathematics Anxiety Test, adopted from Montiel (1995), which seeks to measure the math anxiety level of students in terms of the following constructs: Social Responsibility Anxiety, Mathematics Test Anxiety, and Numerical Anxiety; Lesson Plans which serves as a guide for teaching both groups; Class Observation Form which serves as a checklist for the observer regarding the execution of the lesson on both groups; and a questionnaire followed by an interview of the selected students from the experimental group conducted to elicit students' experiences and reactions during the integration of mathematical modeling in their classroom.

\section{DATA GATHERING PROCEDURE}

Prior to the execution of the study, both groups took a pretest to gauge their problem solving performance and math anxiety level through the problem solving performance test and mathematics anxiety test. Overall, the findings seem to imply that aside from the schedule, teacher, classroom location, and the assumption that the IQ of the participants are comparable based on their grades last period, the pretest scores of both groups show that they are comparable and that they have the same entry level on the subject. Table 2 reveals the respondents' pre-test mean score on problemsolving performance and anxiety.

Table 2. Result of t-test for the Comparison of the Pretest Mean Scores of the Control and Experimental Groups on Problem Solving Performance and Math Anxiety

\begin{tabular}{|c|c|c|c|c|c|c|c|}
\hline Variable & $\begin{array}{l}\text { Test } \\
\text { Items }\end{array}$ & Group & Mean & SD & $\begin{array}{c}\text { Computed } \\
\text { t-value }\end{array}$ & $\begin{array}{l}\text { Critical } \\
\text { t-value }\end{array}$ & Interpretation \\
\hline \multirow[t]{6}{*}{ PSP } & \multirow[t]{2}{*}{ MC } & Control & 8.33 & 2.39 & \multirow[t]{2}{*}{0.669} & \multirow{6}{*}{1.6620} & \multirow[t]{2}{*}{ Not Significant } \\
\hline & & Experimental & 8.72 & 3.17 & & & \\
\hline & \multirow[t]{2}{*}{ FR } & Control & 0.35 & 0.67 & \multirow[t]{2}{*}{0.631} & & \multirow[t]{2}{*}{ Not Significant } \\
\hline & & Experimental & 0.26 & 0.65 & & & \\
\hline & \multirow{2}{*}{$\begin{array}{c}\text { MC \& } \\
\text { FR }\end{array}$} & Control & 8.67 & 2.50 & \multirow[t]{2}{*}{0.497} & & \multirow[t]{2}{*}{ Not Significant } \\
\hline & & Experimental & 8.98 & 3.32 & & & \\
\hline \multirow[t]{8}{*}{ MA } & \multirow[t]{2}{*}{ SRA } & Control & 27.11 & 4.63 & \multirow[t]{2}{*}{0.621} & & \multirow[t]{2}{*}{ Not Significant } \\
\hline & & Experimental & 26.48 & 5.10 & & & \\
\hline & \multirow[t]{2}{*}{ MTA } & Control & 90.78 & 15.46 & \multirow[t]{2}{*}{0.963} & & \multirow[t]{2}{*}{ Not Significant } \\
\hline & & Experimental & 87.91 & 13.01 & & & \\
\hline & \multirow[t]{2}{*}{ NA } & Control & 108.52 & 19.50 & \multirow[t]{2}{*}{1.165} & & \multirow[t]{2}{*}{ Not Significant } \\
\hline & & Experimental & 113.24 & 19.33 & & 1.6620 & \\
\hline & \multirow[t]{2}{*}{ TOTAL } & Control & 226.50 & 33.54 & \multirow[t]{2}{*}{0.208} & & \multirow[t]{2}{*}{ Not Significant } \\
\hline & & Experimental & 227.96 & 33.70 & & & \\
\hline
\end{tabular}

*PSP - Problem Solving Performance, MA - Math Anxiety

* MC - Multiple Choice Items, FR - Free-response Items

* SRA - Social Responsibility Anxiety, MTA - Mathematics Test Anxiety,

* NA - Numerical Anxiety,

*TOTAL - Combined SRA, MTA, and NA

It is evident in table 2 that no significant difference were reflected from each of the mean scores and mathematics anxiety level which means that both of the two groups (the experimental and control groups) were equal in those variables.

There were two kinds of treatment: the integration of mathematical modeling for the experimental group and the guided practice for the control group. Both groups were taught the same 
topics: Quadrilaterals, Triangle Similarities, and The Pythagorean Theorem. The execution of the study lasted for three weeks only (December 1- 18, 2014). Extra handouts, visual aids and other learning materials for the pupils in both groups were provided. This was necessary in order to control the effects of teaching materials and references. To ensure that the teacher-researcher would not show any bias during the execution of the study, two teachers from Eastern Bacoor National High School made a classroom observation for every execution of different activities.

In terms of the structure in teaching, both groups were handled in a student-centered approach where activities and group works are integrated in every lesson proper. However, the experimental group performed a different way of presenting their solutions that would engage them to think further than what is expected from them. The experimental group was exposed to mathematical modeling to deeply interpret the scenario or phenomena that they are meant to explain or answer.

To determine the performance of the students in the experimental group, an indicator was used to provide objective scoring for each group. This indicator was adopted, as shown in table 3, from the "Six Level of Assessing Mathematical Modelling" by Ludwig and $\mathrm{Xu}$, (as cited in Journal für Mathematik-Didaktik 31.1, 2009:77-97).

Table 3. Six Level for Assessing Mathematical Modelling Competency

\begin{tabular}{|c|l|}
\hline LEVEL & \multicolumn{1}{c|}{ CHARACTERISTICS } \\
\hline 0 & $\begin{array}{l}\text { The student has not understood the situation and is not able to } \\
\text { sketch or write anything concrete about the problem. }\end{array}$ \\
\hline 1 & $\begin{array}{l}\text { The student only understands the given real situation, but is not } \\
\text { able to structure and simplify the situation or cannot find } \\
\text { connections to any mathematical ideas. }\end{array}$ \\
\hline 2 & $\begin{array}{l}\text { After investigating the given real situation, the student finds a } \\
\text { real model through structuring and simplifying, but does not } \\
\text { know how to transfer this into a mathematical problem (the } \\
\text { student creates a kind of word problem about the real situation) }\end{array}$ \\
\hline 3 & $\begin{array}{l}\text { The student is able to find not only a real model, but also } \\
\text { translates it into a proper mathematical problem, but cannot } \\
\text { work with it clearly in the mathematical world. }\end{array}$ \\
\hline 4 & $\begin{array}{l}\text { The student is able to pick up a mathematical problem from the } \\
\text { real situation, works with this mathematical problem in the } \\
\text { mathematical world, and has mathematical results. }\end{array}$ \\
\hline 5 & $\begin{array}{l}\text { The student is able to experience the mathematical modelling } \\
\text { process and to validate the solution of a mathematical problem } \\
\text { in relation to the given situation. }\end{array}$ \\
\hline
\end{tabular}

After three weeks of execution, both groups took their posttest in problem solving performance and math anxiety. In terms of the Problem Solving Performance Part II, the scoring of each item was done with the help of the subject teacher to observe triangulation process and to ensure that each item was properly graded. The results of the scoring were presented to the mathematics coordinator for validation purposes and other recommendations.

The results were then compared with the results of their pretest scores. T-test of dependent and independent means were employed to gauge if there was a significant difference between the performances of both groups.

\section{DATA ANALYSIS PROCEDURE}

The following statistical tools were used in this study.

Mean and standard deviation. These were used to describe the respondents' scores in the problem solving and math anxiety test before and after using the pictorial models. 
T-test for dependent samples. This was utilized to determine if a significant difference between the pretest and posttest mean scores of the respondents.

\section{Results and Discussion}

Table 4 shows the result of t-test between the pretest and posttest mean scores of both groups in terms of their problem solving performance and math anxiety. For their problem solving performance, findings showed that there is a significant difference between the two groups which suggests that both group showed improvement in their mean scores while for their math anxiety, findings show that both groups were able to reduce their level of anxiety from moderately anxious to low anxious.

Table 4. Result of t-test for the Comparison of the Pretest and Posttest Mean Scores of the Control and Experimental Groups on Problem Solving Performance and Math Anxiety

\begin{tabular}{|c|c|c|c|c|c|c|c|}
\hline Variable & $\begin{array}{c}\text { Test } \\
\text { Items }\end{array}$ & Group & $\begin{array}{c}\text { Pretest } \\
\text { Mean } \\
\text { Score }\end{array}$ & $\begin{array}{c}\text { Post test } \\
\text { Mean } \\
\text { Score }\end{array}$ & $\begin{array}{c}\text { Computed } \\
\text { t-value }\end{array}$ & $\begin{array}{c}\text { Critical } \\
\text { t-value }\end{array}$ & Interpretation \\
\hline \multirow{6}{*}{ PSP } & \multirow[b]{2}{*}{ MC } & Control & 8.33 & 15.72 & 15.239 & \multirow{6}{*}{1.6794} & Significant \\
\hline & & $\begin{array}{l}\text { Experi- } \\
\text { mental }\end{array}$ & 8.717 & 17.94 & 22.682 & & Significant \\
\hline & \multirow[b]{2}{*}{ FR } & Control & 0.35 & 6.98 & 12.562 & & Significant \\
\hline & & $\begin{array}{l}\text { Experi- } \\
\text { mental }\end{array}$ & 0.261 & 11.89 & 23.100 & & Significant \\
\hline & \multirow{2}{*}{$\begin{array}{c}\text { MC \& } \\
\text { FR }\end{array}$} & Control & 8.67 & 22.70 & 17.460 & & Significant \\
\hline & & $\begin{array}{c}\text { Experi- } \\
\text { mental }\end{array}$ & 8.978 & 29.83 & 30.116 & & Significant \\
\hline \multirow{8}{*}{ MA } & \multirow[b]{2}{*}{ SRA } & Control & 27.11 & 22.52 & 7.635 & \multirow{8}{*}{1.6794} & Significant \\
\hline & & $\begin{array}{l}\text { Experi- } \\
\text { mental }\end{array}$ & 26.478 & 22.565 & 4.752 & & Significant \\
\hline & \multirow[t]{2}{*}{ MTA } & Control & 90.78 & 85.41 & 2.167 & & Significant \\
\hline & & $\begin{array}{l}\text { Experi- } \\
\text { mental }\end{array}$ & 87.91 & 78.61 & 4.159 & & Significant \\
\hline & \multirow[b]{2}{*}{ NA } & Control & 108.52 & 103.94 & 1.096 & & Not Significant \\
\hline & & $\begin{array}{l}\text { Experi- } \\
\text { mental }\end{array}$ & 113.24 & 96.11 & 5.150 & & Not Significant \\
\hline & \multirow[t]{2}{*}{ TOTAL } & Control & 226.50 & 213.15 & 1.946 & & Significant \\
\hline & & $\begin{array}{l}\text { Experi- } \\
\text { mental }\end{array}$ & 227.96 & 197.07 & 5.350 & & Significant \\
\hline
\end{tabular}

*PSP - Problem Solving Performance, MA - Math Anxiety

* MC - Multiple Choice Items, FR - Free-response Items

* SRA - Social Responsibility Anxiety, MTA - Mathematics Test Anxiety,

*NA - Numerical Anxiety,TOTAL - Combined SRA, MTA, and NA

In terms of their problem solving performance, the result shows that the two groups improved their mean scores in both areas though the control group achieved a mean score (22.70) that is below the median score (25.00). However, the increased points are significant which suggests that the group improved their performance in problem solving. In comparison with the components of the test, the control group improved more on the multiple choice items rather than the free- response items. Based on the observation on the participants, it showed that some students are still having a hard time solving word problems especially when it comes to free-response items. It was also observed that some students found it hard to organize their thoughts and failed to follow the process in solving a problem. For the experimental group, the increase of posttest mean score by 20.848 is significant which means that the group was able to show improvement in their problem solving performance in mathematics. Also, the group was able to reach a mean score of 29.826 which is higher than the median score (25.0). This is in agreement with the study of Mousoulides, et al. (2006) where mathematical modeling is proven to be effective in improving the problem solving performance of students. Also, the participants of the study agreed in terms of the effectiveness of mathematical modeling regarding its approach in solving real-life problems. Student (7) saw the 
beauty in its complexity by saying "the activity was very cool! I never imagined that we could solve problems that way. Though it is difficult, but it was fun". However, there are also negative reactions on the purpose of the activity. Student (40) said, "I was intimidated by the complexity of the activity because there are many things to do before I could start with the computation". "I was used to just answering word problems as it is, so this was really new to me", student (10) added.

These mixed reactions from the students showed how the correct execution of mathematical modeling can have an impact on students. When used correctly, mathematical modeling encourages students to stop viewing mathematics as techniques and procedures and start viewing it as a tool to solve problems (Biembengut \& Hein, 2013).

For the math anxiety, both groups have shown a reduction of their anxiety level from Moderately Anxious to Low Anxious. The result agreed with the statement made by Alkan (2013) that group dynamics is one of the factors that could lessen math anxiety. However, it was the experimental group which improved greater than the control group as evidenced by a mean difference of 30.89 compared with control group with a mean difference of 13.35 . In a study made by Temur (2011), it has been observed that as the session progressed, the participants of the study developed positive attitudes towards problem solving and modeling. It is also evident in a recent study which proves that mathematical modeling gets students engaged and interested in mathematics beyond the current mathematics course that they are studying. (Wethall ,2011)

However, in terms of their Numerical Anxiety, though the two groups showed a decrease of anxiety level, it was not statistically significant. This is also evident in the findings of Wilder (2013) where Numerical Anxiety was recorded to be of less significance which was accounted for the smallest part of the variance in the test. In terms of the performance of the participants during the study, it was observed that students found some activities to be difficult, as attested by Student (35), "it is hard and complicated"; "I think the activities are good and useful, but it doesn't change the fact that it made us think very deeply" (Student 8)

\section{COMPARISON OF RESPONDENT'S POST TEST MEAN SCORE AND MATH ANXIETY LEVELS.}

Table 5 shows the result of t-test between the posttest mean scores of both groups in terms of their problem solving performance and math anxiety. For the problem solving performance, the experimental group obtained a higher mean score than the control group while for the math anxiety, the experimental group obtained a lower mean score than the control group.

Based on the mean scores of both groups, the experimental group performed better which suggests that mathematical modeling is more effective than guided practice in improving the problem solving performance of students in mathematics. This is in agreement with the study of Dudley (as cited in Oswalt, 2012) who stated that the primary purpose of a modeling task is to teach students reason, logic, and problem- solving. Temur (2012) also stressed that modeling has an important place in developing a problem solving technique. It has been found out by Fey et al. (as cited in Wethall, 2011) that students who were taught using a modeling approach outperformed the students using a traditional approach on problems that require interpretation of results of algebraic calculations. This is also evident in the posttest answers of students on part II where it can be shown that students from the mathematical modeling group have a systematic way of answering the word problems given. Students also showed how the concepts learned in the class can be applied when solving a certain problem compared with the other group who proceeded with the computation part of the problem. In a study by Chuan (2003), mathematical modeling was used to further teach students in terms of problem solving and it was proven effective in improving student's critical thinking and creativity. Also, Mathematical modeling encourages a deeper comprehension of mathematical ideas and trains students to reflect, interpret, and formulate a plan when presented with a non-traditional problem (Oswalt, 2012). 
Table 5. Result of t-test for the Comparison of the Posttest Mean Scores of the Control and Experimental Groups on Problem Solving Performance and Math Anxiety

\begin{tabular}{|c|c|c|c|c|c|c|c|}
\hline Variable & $\begin{array}{c}\text { Test } \\
\text { Items }\end{array}$ & Group & Mean & SD & $\begin{array}{c}\text { Computed } \\
\text { t-value }\end{array}$ & $\begin{array}{l}\text { Critical } \\
\text { t-value }\end{array}$ & Interpretation \\
\hline \multirow{6}{*}{ PSP } & \multirow[b]{2}{*}{ MC } & Control & 15.72 & 2.40 & \multirow[t]{2}{*}{3.468} & & \multirow[t]{2}{*}{ Significant } \\
\hline & & Experimental & 17.94 & 3.61 & & & \\
\hline & \multirow[b]{2}{*}{ FR } & Control & 6.98 & 3.55 & \multirow[t]{2}{*}{6.810} & & \multirow[t]{2}{*}{ Significant } \\
\hline & & Experimental & 11.89 & 3.37 & & & \\
\hline & \multirow[b]{2}{*}{$\begin{array}{c}\text { MC \& } \\
\text { FR }\end{array}$} & Control & 22.70 & 5.37 & \multirow[t]{2}{*}{5.889} & 1.6620 & \multirow[t]{2}{*}{ Significant } \\
\hline & & Experimental & 29.83 & 6.22 & & & \\
\hline \multirow{8}{*}{ MA } & \multirow[b]{2}{*}{ SRA } & Control & 22.52 & 5.83 & \multirow[t]{2}{*}{0.038} & \multirow{8}{*}{1.6620} & \multirow[t]{2}{*}{ Not Significant } \\
\hline & & Experimental & 22.57 & 5.07 & & & \\
\hline & \multirow[b]{2}{*}{ MTA } & Control & 85.41 & 19.25 & \multirow[t]{2}{*}{2.012} & & \multirow[t]{2}{*}{ Significant } \\
\hline & & Experimental & 78.61 & 12.48 & & & \\
\hline & \multirow[t]{2}{*}{ NA } & Control & 103.94 & 22.73 & \multirow[t]{2}{*}{1.940} & & \multirow[t]{2}{*}{ Significant } \\
\hline & & Experimental & 96.11 & 15.24 & & & \\
\hline & \multirow[t]{2}{*}{ TOTAL } & Control & 213.15 & 45.31 & \multirow[t]{2}{*}{2.034} & & \multirow[t]{2}{*}{ Significant } \\
\hline & & Experimental & 197.07 & 28.72 & & & \\
\hline
\end{tabular}

*PSP - Problem Solving Performance, MA - Math Anxiety

* MC - Multiple Choice Items, FR - Free-response Items

* SRA - Social Responsibility Anxiety, MTA - Mathematics Test Anxiety,

*NA - Numerical Anxiety, TOTAL - Combined SRA, MTA, and NA

In terms of the uniqueness of the approach when solving mathematics problems, the participants strongly agreed that mathematical modeling provided them with that. Student (36) said, "It was very new to me. This is my first time to encounter this type of activity that I don't know what to expect from it." Student (16) found the "new" activity very intimidating and unique but was "grateful for the help of his teacher and peers". Student (25) has a different view on it; he said, "I find it very challenging compared with what we have before. At first, I was confused with the process because it is my first time but after the first activity, the succeeding activities are very fun and informative. It was also reflected in the study made by Chuan (2003) that although it was the first time the groups experienced modeling activities, they were able to progress through the modeling stages successfully. Fox (2006) also stated that mathematical modeling activities move beyond traditional problem solving to encourage children to develop and explore significant, real world mathematical ideas.

In terms of their math anxiety, the experimental group obtained a lower mean score than the control group which reflects lower anxiety level thus, implying that mathematical modeling is more effective than the guided practice in reducing the anxiety level of students in mathematics. This result is attributed to the nature of the modeling activities which makes students engaged and interested in the discussion. Students also agreed that mathematical modeling activities helped them become active participants of the class. Student (37) shared that during the group activity even if he is not the leader, he felt "involved" in the whole discussion, he then said, "when we arrived with our answer, it felt very fulfilling and proud because we kept on changing our answers because we want to make sure that we get the correct answer". Another experience shared by Student (3) was that during the mathematical modeling activities, they kept bouncing off with ideas which sometimes lead to heated arguments and discord among members but luckily, before the activity ends, they were able to patch things up. Student (12), on the other hand, treated the arguments as a plus factor. She believed that "it's okay to argue than to have a dead air within group members. Since I am the leader, I want my members to be involved in the whole thinking process". Discussion, arguments, and brainstorming is expected during the activity because in any mathematical modeling activity, students are left on their own mostly that is why students tend to be more responsible and more involved in the thinking process because it entails less teacher involvement. According to Fox 
(2006), Mathematical modeling activities move beyond traditional problem solving to encourage children to develop and explore significant, real world mathematical ideas making them see the relevance of mathematics in real-life context thus allowing them to lessen their aversion on the said subject.

However, in terms of the Social Responsibility Anxiety, results showed that the two groups have no significant difference. This may be attributed to the nature of groupings to that lead them to have less confidence in their own ability to solve problems. On the observation during the study, some students are still not confident in answering on their own like what student (5) said, "I think I can answer on my own, but most of the times, I ask for an idea from my seatmate in terms of how I should start with the problem, but once I was able to understand the concept, I was able to answer it on my own", this was also the case for student (24) who said that, "I cannot solve on my own because I was used to doing things as a group". For the participants under the modeling activities, though they commend the use of new approach in solving word problems in mathematics, students were overwhelmed by the nature of the activities where they felt that it is really "out of the box" (student 1), "one of a kind" (student 30), and very "challenging" (student 24). Some students frequently complained that the mathematical tasks given to them was not what they are used to but they are willing to embrace it because they could see the application of mathematics in their lives through the activities. (Student 20, 24, 37, 41). This was also evident in the study of Wethall (2011) which showed that students were more willing and were able to try new problems and take risks with the types of mathematical processes they attempt as they recognize a positive impact of the mathematical modeling process and how it relates to their learning.

\section{FINDINGS}

Based on the data gathered, the following are the findings of this study.

1. There is a significant difference between the pretest and posttest mean scores of the respondents in the problem-solving in terms of multiple-choice items and free-response type and combined.

2. There is a significant difference between the respondents' prior and after mathematical anxieties in terms of social responsibility, mathematical test anxiety except for numerical anxiety, however, significant difference has noted for its combination.

3. There is a significant difference between mean performances of the respondents in the two independent groups both in the multiple-choice items and free-response items and its combination.

4. There is a significant difference between math anxiety levels of the group who use mathematical modeling and the group who use guided practice, in terms of all its component namely: Mathematics test anxiety; numerical anxiety except for social responsibility anxiety. However, the use of the combination of all its components has been found to be significant.

\section{CONCLUSIONS}

Based on the findings of the study, the following conclusions were drawn.

1. Both the use of mathematical modeling and guided practice in the classroom significantly increase problem-solving performance of the grade 9 high school students

2. The use of mathematical modeling significantly improve grade 9 high school students' math anxiety level specifically in terms of social responsibility anxiety and mathematics test anxiety. However, it does not affect students' numerical anxiety.

3. Mathematical modeling is more effective compared with the use of guided practice in teaching problem -solving topics in mathematics

4. The use of mathematical modeling, compared with the use of guided practice, in teaching problem-solving, is more effective in reducing the grade 9 high school students' math anxiety 
level specifically in terms of numerical anxiety, mathematics test anxiety and its combination. However, in terms of social responsibility anxiety, both of the two strategies were equally effective.

\section{RECOMMENDATIONS}

Based on the findings, the following recommendations are proposed to help future researchers, curriculum developers, teachers, and school administrators:

1. In terms of instruction, it is recommended for teachers to integrate modeling tasks during their topic discussion since it can help elicit positive reactions from students and help improve camaraderie between students.

2. In terms of the execution of the mathematical modeling tasks, it is recommended to create a task that would also elicit individual work for students since in this study, the modeling tasks were only centered on groupings.

3. It is also recommended that more alternative modeling activities, other than the one presented in this study, be created in such a way that it would be applicable in a day to day basis since in this study, the integration of modeling activities is presented twice per topic discussion only. This is to also to avoid saturation.

4. Consider improving of the use of mathematical modeling that would affect students' numerical anxiety.

5. More researches about the integration of mathematical modeling in classroom are recommended which seek to determine the effects on other factors such as the creative thinking of students and other aspects of problem solving.

6. For future researchers of the study, it is recommended that the duration of the study be for the whole grading period or more than 3 months so that the effect of the integration of the modeling activities will be fully realized and shown by the students. Also, extending the duration of the study can be a test to see how the students can retain the methods of solving problems using mathematical modeling.

\section{References}

[1] Alkan, V. (2013). Reducing Mathematics Anxiety: The Ways Implemented by Teachers at Primary Schools. International J. Soc. Sci. \& Education, 3, 3, $795-807$. Retrieved from http://ijsse.com/sites/default/files/issues/2013/v3i3/Paper-25.pdf

[2] Ärlebäck, J. (2009). Mathematical modelling in upper secondary mathematics education in Sweden (Doctoral dissertation, Linkoping University Institute of Technology). Retrieved from http://www.diva-portal.org/smash/get/diva2:302720/ FULLTEXT02

[3] Bahmei, F. (2011). Mathematical modelling in primary school, advantages and challenges. Journal of Mathematical Modelling and Application, 1(9), 3 - 13. Retrieved from proxy.furb.br/ojs/index.php/modelling/article/download/3774/2597

[4] Basco, L. (2008). The use of native dialect in teaching selected functions: effects on achievement and attitude of high school students in Algebra. (Master's thesis). Philippine Normal University, Manila.

[5] Biembengut, M. S., \& Hein, N. (2013). Mathematical Modeling: Implications for Teaching Modeling Students' Mathematical Modeling Competencies, 481-490. Retrieved from https://www.google.com.ph/url? sa=t\&rct $=\mathrm{j} \& \mathrm{q}=\& \mathrm{esrc}=\mathrm{s}$

$\&$ source $=$ web $\& c d=2 \&$ cad $=$ rja\&uact $=8 \&$ ved $=0 C C o Q F j A B \& u r l=h t t p \% 3 \mathrm{~A} \% 2 \mathrm{~F} \% 2 \mathrm{Fwww}$.resea rchgate.net\%2Fpublication\%2F226475882_Mathematical_Modeling_Implications_for_Teachi ng\%2Flinks\%2F00463528aa060e6d98000000.pdf\&ei=ldHOVI3NNqKgXTjIKICQ\&usg=AFQjCNEbRGKU H9H fey Xqh2lM60FYF wzPoQ 
[6] Blomhøj, M. (2009, June). Different Perspectives in Research on the Teaching and Learning Mathematical Modelling. Mathematical applications and modelling in the teaching and learning of mathematics., 461, 1 - 17. Retrieved from http://milne.ruc.dk/ ImfufaTekster/pdf/461.pdf

[7] Chan, T.M. (2003). Mathematical modelling through children's literature for meaningful problem solving among kindergartners. (Master's thesis). University of the Philippines, Quezon City

[8] Corrective Math (n.d.) Common Problems Experienced by Struggling StudentsRetrieved from https://www.mheonline.com/assets/sra_download/Corrective Mathematics/ MoreInfo/ Miscellaneous/corrective_math_common_problems.pdf

[9] Culaste, I.C. (2011). Cognitive Skills of Mathematical Problem Solving ofGrade 6 Children. International Journal of Innovative Interdisciplanary Research, 1, 120 - 125.

[10]Das, R., \& Das, G. (2013, April). Math Anxiety: The Poor Problem Solving Factor in School Mathematics. International Journal of Scientific and Research Publications, 3(4), 1 - 5. Retrieved from http://www.ijsrp.org/research-paper-0413/ijsrp-p16134.pdf

[11]Dela Cruz, J. K. B. \& Lapinid, M. R. C. (2014, March). Students' Difficulties in Translating Worded Problems into Mathematical Symbols. DLSU Research Congress 2014. Retrieved from http:/www.dlsu.edu.ph/conferences/ dlsu_research_congress/ 2014/_pdf/proceedings/LLI-I009-FT.pdf

[12]Francisco, J. M., \& Maher, C. A. (2005, September). Conditions for promoting reasoning in problem solving: Insights from a longitudinal study. Journal of Mathematical Behavior, 24, 361 - 372 Retrieved from http://www.rbdil.org/articles/journal/ ConditionsPromoting Reasoning.pdf

[13]Fox, J. (2006). A Justification for Mathematical Modelling Experiences in the Preparatory Classroom. Proceedings 29th annual conference of the Mathematics Education Research Group of Australasia, 1, 221 - 228. Retrieved from http://eprints.qut.edu.au

[14]Harms, W. (2012). Math anxiety causes trouble for students as early as first grade. UChicagoNews. Retrieved from http://news.uchicago.edu/article/2012/09/12/math -anxietycauses-trouble-students-early-first-grade

[15]Hewson, S. (n.d.). The Mathematical Problems Faced by Advanced STEM Students. NRICH enriching mathematics. Retrieved from http://nrich.maths.org/6458

[16]Kramarski, B., \& Mevarech, Z. R. (2005). Enhancing Mathematical Reasoning in the Classroom: The Effects of Cooperative Learning and Metacognitive Training. American Educational Research Journal, 40 (1). Abstract retrieved from Sage journals. http://aer.sagepub.com/content/40/1/281.short

[17]Lee - Chua, Q. N. (2012, August 26). Even scientists suffer from math anxiety. Philippine Daily Inquirer. Retrieved from http://newsinfo.inquirer.net/258226/even-scientists-suffer-frommath-anxiety

[18]Lingefjärd, T. (2006). Faces of mathematical modelling. ZDM, 38(2), 96 - 112. Retrieved from http://subs.emis.de/journals/ZDM/zdm062a3.pdf

[19]Ludwig, M., \& Xu, B. A Comparative Study of Modelling Competencies among Chinese and German students. Journal für Mathematik-Didaktik 31.1 (2010): 77-97. DOI:10.1007/s13138010-0005-z

[20] Montiel, T. (1995). Development and Validation of Mathematics Anxiety Scale. (Special Project). Philippine Normal University, Manila.

[21] Mousoulides, N.G., Pittalis, M, \& Christou, C. (2006). Improving Mathematical Knowledge Through Modeling in Elementary Schools. Proceedings 30th Conference of the International Group for the Psychology of Mathematics Education, 4, 201 - 208Retrieved from http://www.emis.de/proceedings/PME30/4/201.pdf 
[22] National Council of Teacher of Mathematics . (2010). Why is Teaching With Problem Solving Important to Student Learning? Problem Solving Research Brief. Retrieved from http://www.nctm.org/uploadedFiles/Research_News_and Advocacy/Research/Clips and Briefs/Research brief_14_-Problem_Solving.pdf

[23] Oswalt, S. (2012). Mathematical Modeling in the High School $\bar{C}$ lassroom. Retrieved from http://etd.lsu.edu/docs/available/etd-07032012124945/ unrestricted/ oswaltthesis.pdf

[24]Parker, M., \& Bedford, D. (2001). Problem Solving and Mathematical Modelling: Applicable Mathematics. Retrieved from http://www.transmaths.org/mmps/ FinalReportKeele.pdf

[25]Perina, K. (2002). The sum of all fears. Psychology Today. Retrieved from https://www.psychologytoday.com/articles/200211/sum-all-fears

[26]Rysdon, A. (2010). Math Students Can Relate To. Retrieved from https://www.chatham.edu/pti/curriculum/units/2010/2/Rysdon.pdf

[27] Suh, J. M. (2007). Tying It All Together: Classroom Practices That Promote Mathematical Proficiency for All Students. Teaching Children Mathematics. Retrieved from http://mason.gmu.edu/ jsuh4/tenure/part4thru8/papers/ Tying_It_All_Together.pdf

[28]Temur, Ö. (2012, February). Analysis of Prospective Classroom Teachers' Teaching of Mathematical Modeling and Problem Solving. Eurasia Journal of Mathematics, Science \& Technology Education, 8(2), 83 - 93. Retrieved from http://www. ejmste.com/v8n2/eurasia_v8n2_temur.pdf

[29] Wethall, N. (2011). The Impact of Mathematical Modeling on Student Learning and Attitudes (Master's thesis, The Evergreen State College). Retrieved from http://archives.evergreen.edu/masterstheses/Accession2010-03MEd/2011/ Wethall_Nicola_MEd_2011.pdf

[30]Wilder, S. (2013). Dimensions of Math Anxiety as Measured by the MARS - Brief: Factor Analysis. Retrieved from http://interstat.statjournals.net/YEAR/2013/ articles/1308001.pdf 